NBER WORKING PAPER SERIES

\title{
THE EFFECTS OF FINANCIAL EDUCATION \\ IN THE WORKPLACE: EVIDENCE FROM \\ A SURVEY OF EMPLOYERS
}

Patrick J. Bayer

B. Douglas Bernheim

John Karl Scholz

Working Paper 5655

\section{NATIONAL BUREAU OF ECONOMIC RESEARCH \\ 1050 Massachusetts Avenue \\ Cambridge, MA 02138 \\ July 1996}

We are grateful to the National Science Foundation (Grant Number SBR94-09043 and Grant Number SBR95-11321), as well as to Merrill Lynch, Inc. for financial support. We would also like to thank KPMG Peat Marwick LLP, and in particular Martha Priddy Patterson, for making available the data used to conduct this study. This paper is part of NBER's research programs in Aging and Public Economics. Any opinions expressed are those of the authors and not those of the National Bureau of Economic Research.

(C) 1996 by Patrick J. Bayer, B. Douglas Bernheim and John Karl Scholz. All rights reserved. Short sections of text, not to exceed two paragraphs, may be quoted without explicit permission provided that full credit, including $(\mathcal{O}$ notice, is given to the source. 


\title{
THE EFFECTS OF FINANCIAL EDUCATION \\ IN THE WORKPLACE: EVIDENCE FROM \\ A SURVEY OF EMPLOYERS
}

\begin{abstract}
We examine the effects of education on financial decision-making skills by identifying an interesting source of variation in pertinent training. During the 1990s, an increasing number of individuals were exposed to programs of financial education provided by their employers. If, as some have argued, low saving frequently results from a failure to appreciate economic vulnerabilities, then education of this form could prove to have a powerful effect on rates of behavior. The current paper undertakes an analysis of these programs using a previously unexploited survey of employers. We find that both participation in and contributions to voluntary savings plans are significantly higher when employers offer retirement seminars. The effect is typically much stronger for non-highly compensated employees than for highly compensated employees. The frequency of seminars emerges as a particularly important correlate of behavior. We are unable to detect any effects of written materials, such as newsletters and summary plan descriptions, regardless of frequency. We also present evidence on other determinants of plan activity.
\end{abstract}

Patrick J. Bayer

Department of Economics

Stanford University

Stanford, CA $94305-6072$

John Karl Scholz

Department of Economics

University of Wisconsin-Madison

1180 Observatory Drive

Madison, WI 53706

and NBER
B. Douglas Bernheim

Department of Economics

Stanford University

Stanford, CA 94305-6072

and NBER 


\section{Introduction}

Since the early work of Becker (1967), economists studying the returns to education have traditionally focused on the relation between education and wages. From the perspective of the associated literature, education creates value by conferring skills that are of use to employers. Clearly, however, this is not the sole economic objective of education. In addition to labor market skills, education may also confer decision making skills. Apart from any affect on labor market performance, these decision making skills may improve an individual's ability to weigh alternatives, exploit opportunities, and achieve personal objectives.

Some of the most complex decisions undertaken by ordinary individuals concern financial issues, such as the determination of retirement income needs, or the allocation of resources among alternative investments. Most individuals make these decisions on the basis of their own judgement, rather than with the help of experts, in large part because the market for financial expertise is imperfect (see Bernheim 1994a, 1996b). It is therefore conceivable that appropriate forms of education may improve the quality of personal financial decision-making.

Existing evidence concerning the relation between education and financial choices is quite limited. Correlations hetween an individual's general level of educational attainment and his or her rate of saving have been documented hy Bernheim and Scholz (1993) and Hubbard, Skinner, and Zeldes (1995). However, as in the literature on returns to education in labor markets, these correlations may be attributable to other related factors. For example, individuals with greater patience presumably tend to remain in school longer, and to save at higher rates. As noted by those studying the relation between wage and schooling (see e.g. Card, 1995), causal inferences about the effects of education are potentially misleading unless they are derived from sources of variation in education that are plausibly exogenous.

One particularly pertinent source of variation in education concerns the availability of financial education in the workplace. According to one recent survey, as of 1994,88 percent of large employers 
offered some form of financial education, and more than two-thirds had added these programs after $1990 .^{1}$ Typically, employers provide information and guidance on a range of topics related to retirement planning. While nearly all such programs cover principles of asset allocation, sizable majorities treat retirement income needs ( 73 percent) and retirement strategies ( 88 percent). ${ }^{2}$ If, as argued by Bernheim (1994a, 1995a), low saving frequently results from a failure to appreciate economic vulnerabilities, then education of this form could prove to have a powerful effect on rates of saving.

It is doubtful that the availability of employer-based retirement education is entirely unrelated to workers' underlying predispositions to save. However, there are a variety of reasons (discussed below) to believe that employers adopt these programs as remedial measures in instances where employees are disinclined to save. If this is the case, then cross-sectional estimates of the relation between saving and education may provide lower bounds on the causal effects of education. In addition, since many of these programs have heen adopted quite recently, it may be possible to control for an unobserved predisposition to save by contrasting the behavior of the same individuals before and after educational interventions.

In this paper, we study the behavioral effects of financial education in the workplace using survey data collected from employers who sponsor pension plans. Our analysis is based in part on estimates of the cross-sectional relations between various forms of education and plan activity. Since the data contain repeated observations on many tirms, they also permit us to evaluate the direction of the probable bias in cross-sectional estimates by testing the hypothesis that educational is remedial (through an examination of the circumstances under which programs are adopted or expanded). Moreover, the longitudinal data allow us to control explicitly for unobserved (firm-level) fixed effects.

Despite the growing importance of employer-based retirement education, existing evidence on this

\footnotetext{
l"Employees getting morc: Investment education, planning help on the increase," Pensions \& Investments, January 23 , 1995, p. 74.

${ }^{2}$ See Employee Benefit Research Institute (1995, p. 15).
} 
topic is largely contined to qualitative surveys and case studies (see e.g. Employee Benefit Research Institute, 1994, 1995, A. Foster Higgins \& Co., Inc., 1994, Borleis and Wedell, 1994, or Geisel, 1995). One exception is Bernheim and Garrett (1996), who use a novel household survey to study the effects of these programs. Their analysis is complementary to the current paper; we discuss the relations between these studies in greater depth below.

The remainder of this paper is organized as follows. After describing our data (section 2), we provide an analysis of the circumstances under which employers offer retirement education (section 3 ). While certain kinds of education are more common at organizations that offer self-directed pension plans (such as 401(k)s and 403(h)s), even employers that offer defined benefit plans (and nothing else) frequently provide some form of financial education. For $40 \mathrm{l}(\mathrm{k})$ plans in particular, the data indicate that low participation among non-highly compensated employees is a strong predictor of the adoption and/or enhancement of educational offerings. At least in the context of $401(\mathrm{k})$ plans, education therefore appears to be remedial, in the sense that it is made available to those who are least inclined to save. In part, this may be a consequence of non-discrimination requirements, which limit contributions of highly compensated employees as a function of contributions by non-highly compensated employees. Based on this finding, one would expect cross-sectional estimates of the relation between participation (contributions) and education to be biased against the conclusion that education enhances participation and contributions to self-directed plans.

In section 4, we examine factors correlated with participation in and contributions to 401 (k) plans. We find that both measures of activity are significantly higher when employers offer retirement seminars. The effect is much stronger for non-highly compensated employees than for highly compensated employees. The frequency of seminars emerges as a particularly important correlate of behavior, We are unable to detect any effects of written materials, such as newsletters and summary plan descriptions, regardless of frequency. We obtain similar results based on longitudinal patterns, as well as for an 
assortment of estimation methods. In light of the likely bias mentioned in the previous paragraph and discussed in more detail in section 3 , these findings are strongly consistent with the efficacy of retirement seminars, and they do not rule out the possibility that other forms of education are also effective.

In studying the relation between $401(k)$ activity and education, we control for a variety of plan features. The effects of these features are, of course, of independent interest, and have been the subject of several prior analyses (see Poterba, Venti, and Wise, 1994, Papke, Petersen, and Poterba, 1993, Papke, 1995, Andrews, 1992, Kusko, Poterba, and Wilcox, 1993, and Scott, 1994). Generally, we find that the existence of an employee match is strongly related to $401(\mathrm{k})$ contributions, and especially to participation, in cross-sections. However, this effect is not readily apparent in longitudinal data. There is relatively little indication that any measure of $401(\mathrm{k})$ activity is significantly related to loan provisions. Investment options have no detectable effect on participation, but contributions tend to be a bit higher when greater flexibility is offered.

The paper closes with a brief conclusion.

\section{Data}

The data for our analysis come from the 1993 and 1994 versions of the KPMG Peat Marwick Retirement Benefits Survey. In 1993, KPMG Peat Manwick selected approximately 1100 employers at random from a list of all the private and public employers in the United States with at least 200 employees. If they were willing to participate again, these same employers were retained for the 1994 survey. Any employers who declined to participate in 1994 werc replaced with a randomly selected employer from the same industry, region, and employer-size category.

In each year, these employers were questioned by telephone about the administration, features, and employee utilization of their retirement plans. Some basic employer data, such as total employees, sales, and industry, are available for all respondents. In addition, those employers who have a retirement plan (910 in 
1993 and 861 in 1994) provide some general information about their plan, including the number of employees covered by the plan, the types of plans offered, and the extent to which financial education and guidance is provided by the employer to help cmployees invest for retirement. Furthermore, for each type of retirement plan that a firm offers, the survey contains detailed questions about its features, eligibility requirements, and employec aclivity.

Those employ'ers who offer $40 \mathrm{l}(\mathrm{k})$ plans (596 in 1993 and 566 in 1994) report the features of their plan, including the arailability of an employer match, the matching rate provided, whether hardship withdrawals and loans are permitted, and the number and type of investment options available to a participant in the plan. The survey also allows us to detcrmine which employee groups, such as union, salaried, or parttime employees. are cligible to participate in the plan. In addition, participation and contribution rates are provided for the employecs cligible for the $40 \mathrm{l}(\mathrm{k})$ plan. Thus, for a large sample of over 500 firms each year, the survey provides a rich set of plan characteristics and utilization rates. The variables that we focus on in this study fall into three catcgories: basic firm characteristics (where the firm is the unit of analysis for the study); general plan characteristics, encompassing all retirement plans offered by the firm; and $40 \mathrm{l}(\mathrm{k})$ plan characteristics.

With respect to the first calegory, we experimented with a number of basic firm characteristics (including sales and dummy variables for industry and region), but generally found that they had very little effect on our results. For most of the results presented in this paper, we have retained only one general firm characteristic: the total number of employees. ${ }^{3}$

The second group of variables includes general features of the firm's retirement programs. The most important of these describe the extent to which the firm provides financial education to its employees. Specifically, the survey asks each respondent how often the firm provides summary plan descriptions, employee newsletters or other periodic publications, investment seminars for all employees, seminars for

\footnotetext{
${ }^{3}$ Since the data were provided to us without firm identifiers, we were limited to information collected by the survey.
} 
employees over age 50 , and seminars for employees within a year or two of retirement. Each respondent was asked whether the firm used these devices often, sometimes, rarely, or never. To incorporate the qualitative nature of these responses into our analysis. we use these responses to create three dummy variables for each educational device. The first indicates whether the device is used often, the second indicates whether it is used sometimes or rarely, and the third indicates it is never used. We combine the responses "sometimes" and "rarely" because the data have limited ability to identify educational parameters, and since the subjective distinctions between these responses seem the most likely to differ across respondents. ${ }^{4}$

Other pertinent characteristics of an employer's overall retirement program covered by the survey include information on the composition of retirement plans (e.g. $401(\mathrm{k}) \mathrm{s}$, defined benefit, profit sharing, and so forth), and the fraction of employecs who are covered by a retirement plan. Unfortunately, the survey collects coverage information on a firm-wide basis, rather than plan-by-plan.

The final category of variables includes characteristics of $401(k)$ plans. These include dummy variables for whether loans are permilted and whether an employer match is provided. We also calculate a measure of the number of different kinds of investment options (employer stock, guaranteed income contracts, equity mutual funds, corporate bond funds, government funds, and other funds) available to plan participants. Other survey questions allow us to determine if certain employee groups, such as union, part-time, or salaried employees, are eligible for the plan.

For $40 \mathrm{l}(\mathrm{k})$ plans, we construct participation and contribution rates for eligible employees. The survey

${ }^{4}$ The results in this paper do not change qualitalively when we use other groupings of the responses to these questions. In order to verily the robustness of our results and to reduce still further the number of parameters, we also occasionally define a single variable measituing the intensily of the educational offering. The variable is set equal to 3 if the device is used often, 2 if it is sometimes used, $I$ if it is rarely used, and 0 if it is never used.

\footnotetext{
${ }^{5}$ The suvey also provides information about other potentially useful plan features, such as hardship withdrawals and the actual matching rate provided by the firm. Unfortunately the usefulness of these variables is diminished by data limitations and we therefore do not include them in our specifications. For example, in each year of the survey over 94 percent of employers allow hardship withdrowals, so there is not enough variation in the data to examine their effect on plan activity. Also, fewer than 40 percent of the employers who offer an employer match report the actual matching rate. Therefore, incorporating the actual rate into our specifications ivould severely limit the sample size available for estimation.
} 
provides measures of $40 \mathrm{l}(\mathrm{k})$ plan activity for three categories of employees: all, highly compensated (HC), and non-highly compensaled (NHC). All eligible employees are classified as either HC or NHC according to specific rules set forth in the applicable non-discrimination provisions. These rules were instituted to ensure an equitable distribution of benclits from pension plans. In the context of $401(\mathrm{k}) \mathrm{s}$, they operate by limiting the amounts that highly compensated employees can contribute as a function of contributions by non-highly compensated employecs. An individual is classified as highly compensated if he or she meets any of a number of specific criteria (e.g. earnings of roughly $\$ 100,000$ or more, ownership of more than 5 percent of the company, or earnings of roughly $\$ 65,000$ or more if this amount is in the top quintile of the firm's salary distribution). In addition to participation rates, the survey also provides contribution rates as a percentage of salary for plan participants. ${ }^{6}$ Once again, these figures are provided separately for all employees, HC employees, and NHC employees. Taking the product of participation rates and average contribution rates conditional on participalion, we obtain average contribution rates conditional on eligibility.

Summary statistics for $40 \mathrm{I}(\mathrm{k})$ participation and contribution rates are provided in Table 1 . Mean participation rates are slightly Icss than 60 percent for NHC employees, roughly 80 percent for HC employees, and just over 60 percent overall in both 1993 and 1994. The distribution of participation rates for $\mathrm{HC}$ employees is highly skewed (with oulliers on the lower tail), causing the median participation rates to be about 10 percentage points higher than the mean rates. Participating employees generally contribute between 5 and 7 percent of their salarics, with $\mathrm{HC}$ employees contributing approximately one percentage point more than NHC employces. In both ycars, contribution rates for eligible employees averaged just under three percent for NHC cmployecs. over five percent for HC employees, and between three and four percent overall.

\footnotetext{
${ }^{6}$ While the survey asks for the average contribution as a percentage of compensation, it is not completely clear from the wording whether it means the average over contributors, or the average over eligibles. The designers of the survey suggest the former is the natural interpretation. Given the data, this interpretation appears to be correct. We calculated the average contribution for companies that reported participation rates from 0 to 25 percent, 25 to 50 percent, 50 to 75 percent, and 75 to 100 percent. There was no evidence of systematic variation in contributions over these categories. If companies were reporting the average over eligibles, then the average would (as a purely mechanical matter) have to rise steeply across these categories.
} 


\section{The Availability of Retirement Education}

As a first step in our analysis, we provide descriptive information concerning the availability of different kinds of retirement education in the workplace. Overall, in 1993 nearly 74 percent of pension plan sponsors provided summary plan descriptions, roughly 65 percent distributed newsletters, and just over 44 percent offered retirement seminars to all cmployees. When firms are weighted by total employment, summary plan descriptions and newsletters appear to be somewhat more common (roughly 80 percent in each case), but the frequency of seminars is cssentially unchanged ( 44 percent). The fraction of firms providing summary plan description was somewhat lower in 1994 than in 1993, but the fractions providing newsletters and seminars rose slightly.

Since our ultimate objective is to craluate the relation between education and behavior, it is important to develop an understanding of the sources of variation in educational offerings across firms. Plan sponsors are presumably more likely to provide information when participants are required to make decisions. It is therefore natural to speculate that the growth of educational offerings results in large part from the rising popularity of self-direcled plans such as $40 \mathrm{l}(\mathrm{k}) \mathrm{s}$ and $403(\mathrm{~b}) \mathrm{s}$ (see EBRI, 1995, or the extended discussion in section 3 of Bemheim and Garrett, 1996). Yet the KPMG Peat Marwick survey data reveal that seminars, newsletters, and summary plan descriptions are nearly as common among firms with defined benefit plans (43.8 percent, 68.9 percent, and 73.1 percent, respectively for 1993) as among firm with $401(\mathrm{k}) \mathrm{s}(44.4$ percent, 71.2 percent, and 80.1 percent, respectively for 1993).

The preceding finding raises the possibility that many employers provide retirement education to address general concerns aboul cmployees' prcparation for retirement, rather than to equip them with planspecific decision-making skills. One need not construe this as necessarily altruistic. Education may help employecs to appreciate the values of their pension plans. By promoting adequate preparation for retirement, an employer may also hope to avoid subsequent conflicts (e.g. over demands for more generous pension benefits) with older, poorly prepared workers. Assistance with financial planning may also enhance employee 
loyalty, improve labor relations, and boost morale.

Of course, comparisons based on raw frequencics, such as those described above, may be misleading. For example, it is common for employers to offer both a defined benefit plan and a supplemental $401(\mathrm{k})$. It is therefore possible that the frequency of educational offerings at organizations with defined benefit plans in part reflects the presence of secondary $401(\mathrm{k})$ plans. Also, it is conceivable that educational offerings may differ systematically by company characteristics that are related to the presence of defined benefit plan.

To investigate this possibility, we estimate probit models explaining the availability of seminars for all employees, seminars for employees over 50 years of age, seminars for employees nearing retirement, summary plan descriptions, and newslelters or periodicals. Results are contained in table 2. Explanatory variables include variables measuring the types and variety of plans (where the omitted category is "only a defincd benefit plan"), cmployment. plan coverage, and year. The data are pooled across years, and the standard errors are corrected to account for potential correlation across observations from the same organization.

Focusing attention on organizations with a single plan, it is evident that seminars of all kinds are most common among non-prolit institutions with 403 (b)s. Companies with $401(\mathrm{k}) \mathrm{s}$ are more likely to offer seminars to all emplosees than companies with defined benefit or other kinds of plans, but less likely to offer seminars specifically for older employecs. Written materials of all kinds are most commonly used among companies with $401(\mathrm{k}) \mathrm{s}$, but there are no significant differences between the likelihoods that sponsors of other kinds of plans provide such materials. Thus, while the rising popularity of self-directed plans may have promoted the growth of certain educational offerings, the impetus for this growth appears to be much more general. This is consistent with the findings of Bernheim and Garrett (1996).

Table 2 also indicates that educational of $\int e r i n g s$ are significantly more common among organization with multiple plans. Employment and coverage are positively correlated with seminar offerings, but not with the availability of written materials. This may reflect the presence of economies of scale in the provision of 
seminars. Gencrally, the frequencies of educational offerings did not change appreciably between 1993 and 1994.

When analyzing the relation between education and behavior, we must necessarily restrict attention to organizations with plans that pennit employecs to make choices. We therefore focus our attention on $401(\mathrm{k}) \mathrm{s}$. Since the detcrminants of education offerings relate to the selection process determining the incidence of "treatment," it is important to recxamine the determinants of these offerings specifically in the context of $40 \mathrm{l}(\mathrm{k}) \mathrm{s}$. If, for example, education tends to be offered in response to a demand for information by employees who are naturally inclined to save at high rates, then positive cross-sectional correlations between education and $40 \mathrm{l}(\mathrm{k})$ aclivity could reflect selection, rather than the influence of employer-based education on employee behavior. If, on the other hand, companies tend to provide education as a remedial measure to employees who are otherwise disinclined to save, then the nature of selection could obscure an underlying relation betwecn education and behavior

Analogously to table 2, table 3 provides cstimates of probit models explaining the availability of various educational offerings in the poolcd 1993/94 sample. In this instance, however, we have confined attention to companies with $40 \mathrm{l}(\mathrm{k}) \mathrm{s}$. We have also added several new explanatory variables, including the number of categories of investment options (c.g. cmployer stock, guaranteed income contracts, bond funds, equity mutual funds, and so forth) available to participants, and dummy variables indicating whether the plan covers union employees, whether it provides for an employer match, and whether loans are permitted.

As in table 2, seminars for older workers are more likely when companies offer plans other than $40 \mathrm{l}(\mathrm{k}) \mathrm{s}$, and the likelihood of seminar offerings generally tends to rise with employment. Notably, education does not appear to be more common among plans that cover union employees. Since employees presumably have greater leverage when they are unionized, this casts doubt on the hypothesis that education is provided

${ }^{7}$ Unfortunately, this variable is not available for delined benefit plans, and therefore could not be included in the regressions of table 2 . 
in response to employee demand. It is also notable that the correlation between seminars and employer matching provisions is negative (though not significant at conventional levels). This is consistent with the view that education and matching are substitutable methods of encouraging participation in situations where employees show insufficient intercst in the plan. Not surprisingly, education of all forms is significantly more likely when employers offer participants more investment options. There is also some indication that seminars and loan provisions are positively correlated.

Thus far, we have not cxploited the longitudinal features of our data. Doing so permits us to examine the circumstances under which employers establish or expand educational offerings. Specifically, we regress the change in seminar offerings between 1993 and 1994 on a variety of "initial" (1993) company and pension plan characteristics. For the purpose of this analysis, we measure the change in seminar offerings as the difference between the "intensity" of seminars (measured on a scale of 0 to 3) in 1993 and 1994 (see footnote 4).

Results appear in table 4. Separate results are presented for each of our five educational categories. The most striking feature of this table is the pattern of negative coefficients for the initial participation rate of NHC employecs in the specifications explaining changes in seminar offerings. In the case of seminars for all employees, the coeflicient is highly significant: it is marginally significant (i.e. with slightly less than $95 \%$ confidence) for the other two seminar variables. This implies that low participation among NHC employees is strongly associated with subsequent increases in employer-sponsored seminars. This result does not, however, carry over to written materials. No other variable consistently passes tests for statistical significance at conventional levels. The coefficients of the initial HC participation rate are also negative for the seminar variables, but their magnitudes and levels of significance are smaller. With low confidence, the estimates indicate that educational improvements were more likely among firms with pensions plans that covered larger fractions of employees. Improvements in age-specific seminars were also less common among larger firms and among unionized firms. There is little if any relation between initial pension plan 
characteristics and subsequent changes in educational offerings.

The paltern documented in table 4 supports the hypothesis that, in the context of $401(\mathrm{k}) \mathrm{s}$, retirement seminars are remedial. These offerings appear to be motivated by low participation among NHC employees. This is consistent with the view that non-discrimination requirements provide a powerful impetus for the provision of retirement educalion among $40 \mathrm{l}(\mathrm{k})$ sponsors. However, it is doubtful that this is the only motivation. If it were. then high initial HC participation would also correlate with subsequent increases in education, which is not the case. The small negative effect of initial HC participation probably reflects the offsetting effects of two separate considerations: first, that employers are inclined to offer education as a remedial measure when $401(k)$ activity is low (regardless of HC or NHC status), and second, that employers also use education to address binding non-discrimination constraints (which tend to arise when HC participation is high). These findings are consistent with the indirect evidence on selection offered by Bernheim and Garrett ( 1995$)$.

\section{Evidence on Participation in and Contributions to 401(k) Plans}

In this section we use the KPMG Peat Manvick plan-level data to examine factors associated with participation in and contributions to $40 \mathrm{I}(\mathrm{k})$ plans. We use cross-sectional data on all the firms in our sample and also examine changes for the same firm over 1993 and 1994. While we focus on the role employer-based education plays in these decisions, we cxamine scveral other plan and firm characteristics that may be related to participation and contributions

\section{A. Factors affecting participation in self-directed plans}

The first step in our analysis of $401(k)$ activity is to examine cross-sectional OLS regressions of planlevel participation rates. Since there are strong similarities between the data for 1993 and 1994, and since we are not interested in investigating any specific hypotheses about the differences between these years, we pool the two surveys. We include a year dummy to account for any systematic factors that might influence 
participation or contributions differently through time. As in the previous section, pooling the data raises one important empirical issue: since many of the same firms were surveyed in both years, it is doubtful that the error terms are independent across all observations. While OLS estimates are still consistent under these conditions, the conventional method of computing standard errors is inapplicable. In our reported estimates, we again correct our standard errors to reflect clustered sampling.

Since nondiscrimination rules are binding for many employers (Garrett, 1996), education programs may be designed to encourage participation by NHC cmployees. Moreover, since HC and NHC households start out with different levels of financial sophistication, we would expect financial education to affect their behavior differently. For both reasons, we estimate separate regressions for these groups as well as for the combined sample.

Results are contained in the lirst panel of table 5 . The dependent variables for these regressions - the plan participation rates - vary from I to 100 percent. The estimated effects of the key explanatory variables are described below.

\section{i. The role of seminars}

For our base-case estimates, we use dummy variables to measure the intensity (frequency) of educational offerings. In this way, we aroid imposing assumptions on the functional relation between participation and an arbitrarily scaled measure of education (as discussed in section 2, we do, however, use the same dummy variable to represent the responses "sometimes" and "rarely"). In subsection D, we also present results based on a single scalar measure of educational intensity. We also focus exclusively on seminars for all employees, rather than on scminars targeted at employees over 50 or employees near retirement. In practice, the seminar variables are highly colinear, and it is difficult to identify their separate effects with precision.

Reading across the first lwo rows of the first panel of Table 5, it is apparent that frequent seminars have a consistently positive and significant effect on participation in self-directed plans. For non-highly 
compensated employees, frequent seminars are associated with participation rates that are 11.5 percentage points higher than plans with no seminars. The corresponding figure for highly compensated employees is 6.4 percentage points. These are economically large estimates given mean participation rates -60 to 80 percent - in the sample. The occasional scminar indicator variable is, however, insignificant in each specification.

The results in table 5 may obscure the relation between education and participation among HC employees. Although censoring at the plan level (at either 0 percent or 100 percent) is relatively rare for "all" employees and for NHC employees, it is much more common for $\mathrm{HC}$ employees. Specifically, for 32 percent of the sample, the HC participation rate is 100 percent. Obviously, increases in seminars and changes in other plan characteristics cannot be associated with higher participation rates for companies that achieve 100 percent $\mathrm{HC}$ participation. We investigate the effects of censoring in section $\mathrm{D}$, below, where we estimate Tobit specifications

These results arc consistent with the lypothesis that seminars stimulate $401(\mathrm{k})$ participation generally, and especially among NHC cmployecs. This implies that retirement seminars may be an effective response to non-discrimination rules. However, there is no indication in the pooled results that seminars matter unless they are conducted frequently.

\section{ii: Other forms of education and information dissemination}

We include scrcral additional education variables (newsletters and summary plan descriptions) to examine whether all educational and informational efforts are equally effective. Summary plan descriptions typically amount to disclosure of plan characteristics, and contain very little (if any) recognizable education. While it is perhaps conceivable that employecs would be unwilling to trust (and therefore to participate in) their pension plans without disclosure, we would nevertheless be surprised if the use of these materials had a measurable effects on plan activity. In contrast, ncwsletters often serve the same function as seminars, but provide information through printed, rather that audio-visual media. According to a survey by the Employee 
Benefit Research Institute. 92 percent of $401(\mathrm{k})$ participants say that they read these materials, and 33 percent say that they contribute more to their plans as a result. One might therefore expect newsletters to have an effect on behavior similar to that of seminars. Alternatively, individuals may exaggerate their responses to newsletters in response to survey questions, particularly if they perceive this to be the "appropriate response."

Notably, in the regressions of table 5, aside from seminars, no other medium of providing information and education to employecs - cither through newsletters or summary plan descriptions - has any significant association with participation rates. This is consistent with the hypothesis that these media have no effect on participation. In principle. selection bias could mask a behavioral response. However, in contrast to seminars, there is little indication in the results of section 3 that the provision of written materials is motivated by low participation.

\section{iii. Plan characteristics}

There is mixed cvidence in the literature on the effect of matching rates on participation in self-directed plans, despite the fact that matching is very common. According to a 1990 Hewitt and Associates survey, 79 percent of 944 major U.S. corporations matched employee contributions. Papke (1995) finds a strong, positive relationship between match rates and participation in cross-sectional regressions using data from Form $5500{ }^{8}$ The effect disappears in her preferred, fixed effects specification. Andrews (1992) uses data from the Current Population Survey and finds a positive relationship between the presence of a match and participation ralcs. Kusko. Polcrba, and Wilcox (1994) cxamine data from a single firm over several years, where the match rate varied from 0 to 139 percent of employee contributions (up to six percent of salary). They found little variation in participation rates across years, which lead them to conclude that their results suggest "a relatively sinall clasticity of participation with respect to the match rate, and cast substantial doubt

\footnotetext{
${ }^{8}$ Form 5500 is liled annually with the IRS by all sponsors of pension plans with more than 100 participants. The data include plan eligibility, participation, employment, administrative cost, distributions, and contributions
} 
on the view that employer matching is a key factor in explaining the rapid expansion of $40 \mathrm{l}(\mathrm{k})$ plans." However, the $401(k)$ sponsored by the firm examined by Kusko, Poterba, and Wilcox was part of a profitsharing plan, and hence had unusually volatile match rates. It is not clear that one can generalize from participation responses in prolit-sharing plans to more common plan types, where match rates change much less frequently. In principal, we expect matching rates to exert a positive effect on participation since they provide a pure substitution effect at the extensive margin.

In all the cross-scctional regressions we have examined, there is a positive and significant correlation between the existence of a match and participation. ${ }^{9}$ The regression results in table 5 imply that plans with matches have participation rates that are 14.6 to 16.9 percentage points higher than plans without matches

Loan provisions allow familics to borrow against contributions made to the self-directed plan. Conventional reasoning suggests that eligible workers will be more likely to participate in plans with loan provisions since they will have access to funds in the event they need to borrow. An alternative view holds that loan provisions will be negativcly corrclated with participation because they exacerbate "self-control" problems wilh saving (sec c.g. Shelfrin and Thaler, 1988). We find that the correlation between the existence of loan provisions and participation are positive but insignificant in the regressions for all employees, and negative but insignificant in the separate regressions for $\mathrm{HC}$ or NHC employees.

Having a broad range of investment options presumably increases the attractiveness of participation. The number of options in these plans is not particularly large, with a mean of 2.8 in 1993 and a mean of 3.7 in 1994. A single investment option can be narrow (say stock in the employee's company, or a guaranteed life insurance contracts), or broad, like the Fidelity family of mutual funds. Although we expect investment options to be positively corrclated with participation, this effect is not significant in any specification.

Conceivably, this finding may be attributable to the coarseness of our measure for the number of options

\footnotetext{
${ }^{9}$ Recall from section 2, that data on the level of match is missing for a large number of observations so we use only an indicator variable for whether the lim olfers a match
} 
(e.g., the vast family of Fidelity equity mutual funds would be considered one option).

\section{iv. Firm characteristics}

An obvious concern with cross-seclional estimates of the kind considered here is that the variables of interest may be correlated with unobserved firm-specific characteristic. In that case, the correlations that we attribute to seminars may in fact reflect other factors. In addition to the plan characteristics already mentioned, we therefore include a set of firm-specific variables to try to account for other pertinent factors.

The existence of other pension plans should matter for two distinct reasons. First, other pension plans may be positively correlated with participation in a self-directed plan. There is extensive evidence that the existence of a $40 \mathrm{l}(\mathrm{k})$ is posilively correlated with employees' tastes for saving (Engen, Gale, and Scholz, 1995; and Bernheim 1996a). It is likely that the same is true for other pensions. Thus, the presence of pensions may be positively correlated with participation in self-directed plans. Second, other pension plans may reduce the likelihood of participation in a self-directed plan because the pension may provide households with sufficient retirement saving.

As would be expected if pensions and self-directed plans are initiated in response to employees' wishes, participation rates are higher in self-dirccted plans when the sponsoring firms offers at least one other pension plan. The effect for all employees is significant at conventional levels.

There may be systematic differences in self-directed plan offerings depending on the size of the firm, and on the number of employecs covered by the plan. These differences might, for example, arise from economies of scale in plan adıninistration, or from correlations between size and other variables, such as plan age, unobscrved dimensions of plan generosity, or the nature of peer group effects. We include the number of employ'ees in the firm to capture variations in participation that may be associated with firm size, and the fraction of employees covered to capture variations in participation that may be related to plan size. We find that firm size is negatively associated with participation, but that participation rises significantly with the fraction of employees covered. 
The unionization indicator variable is consistently insignificant across specifications.

\section{v. Summary}

In pooled cross-sectional regressions, there are a number of factors that are significantly associated with participation, including match rates and certain characteristics of the company. The effect of frequent seminars is economically large, positive, statistically significant. No other educational variable significantly affects participation. In light of the selection issue documented in section 3, there is reason to believe that these estimates understate the behavioral impact of retirement seminars, but may accurately reflect the impact of written matcrials

\section{B. Factors related to contributions in self-directed plans}

As indicated in table 1 , the surey collects information on average contribution rates for plan participants. Multiplying the average contribution rate times the participation rate gives the average contribution rate across all eligibles. We use this as our dependent variable to examine contributions Because the data are aggregated across plans, there is no obvious way to use information on the fraction of nonparticipants and the conditional mean among participants separately without making strong ad hoc assumptions on the data. Since the conditional mean among participants is of limited intrinsic interest, we therefore use the transformed contribution variable.

Obviously, our contributions variable may inherit some of the properties of our participation variable. Even so, there is no compelling reason to expect, a priori, that contributions will vary with education in the same way as participation. To sec why, consider the following example. Suppose a firm's employees differ in their taste for saving. Those with a high taste will participate in self-directed plans when available and, due to the tax subsidy (and possibly cmployer match), devote a relatively high fraction of salary to these plans. Employecs with low tastes for saving will choose not to contribute. Now suppose frequent seminars induce employees with low tastes for saving to contribute. If they contribute at low levels, the mean contribution, conditional on participalion, may actually fall, unless education also encourages high savers to 
save even more. It is conccivable, howcrer, that education might actually reduce saving among those who would otherwise put away "too much" relative to standard rules of thumb. Thus, even the unconditional mean of the contribution rate might fall with cducation.

As is clear from the second panel of Table 5 , the frequent seminar variable is positively and significantly associated with contributions for the regressions involving all employees and non-highly compensated employees. The effect is quite large. Mean (unconditional) contribution rates are around 3.4 percent of salary, so the estimates imply that contributions are nearly 20 percent larger in firms offering frequent seminars. This result is consistent with the hypothesis that retirement education - and frequent seminars in particular - positively aflect the size of contributions to self-directed plans.

In the specification for all cmployecs, both match rates and loan provisions are positively and significantly associated with contribution rates. Larger firms have lower contribution rates (the effect is significant for highly-compensated cmployecs). The larger the fraction of employees covered by a selfdirected plan, the higher are contribution rates (the effect is significant for non-highly compensated employees and the all cmployecs specification).

\section{Longitudinal evidence on participation and contributions}

The specifications displayed in table 5 use pooled data from 1993 and 1994. To control for spurious factors that might generate an apparent cross-sectional relationship between seminars and participation or contributions, we included a number of plan- and firm-specific variables. Nevertheless, a skeptical reader might question these results on the grounds that seminars are correlated with other firm-specific characteristics, such as the degree of interest management takes in their employees, and that these other characteristics are responsible for the observed correlation with behavior (perhaps through plan generosity, which is only imperfectly accounted for in our specification).

As discussed earlier, we have observations in both years for nearly 300 firms. Thus, it is possible to repeat our analysis, differencing the data for our short (2-year) panel. While differencing removes time- 
invariant plan-spccific characteristics, it also exacerbates any measurement error problems that might be present, making it more difficult to cstimate correlations that arise from behavioral relationships.

The first panel of table 6 examines participation, repeating the same specification as shown in table 5 , but using the first-differenced data. Although the statistical significance of the results is not quite as striking, this is probably to be cxpected because the sample size is considerably smaller and because of the problems arising from differencing short panels. Nevertheless, we find that instituting seminars on a frequent basis is associated with a 7.7 percentage point increase in participation rates, and the effect is significant at the 11 percent level for the all-employee sample. For non-highly compensated employees, the effect is 12.1 percentage points, and it is significant at the 7 percent level. It is worth noting that the estimated effects of occasional seminars appear stronger in the differenced estimates. Indeed, the effects of frequent and occasional seminars now appear to be roughly proportional.

We view this as further support for the hypothesis that retirement education - and frequent seminars in particular - influence the saving bchavior of employees. Naturally, we cannot resolve the question of causality with only two ycars of data: it is. for cxample, conceivable that employees might agitate for seminars once they start participating (though it is doubtful that their employer would respond over such a short time (rame).

Our results on match rates follow the pattern observed in the literature. Although we find that match rates appear to have a strong, positive corrclation with participation and contributions in cross-sectional data, the effect disappears when one follows the same firms over time. Because actual changes in match rates are infrequent, it is possible that "observed" changes are dominated by measurement errors, in which case the panel estimates of the matching effect may be highly misleading. Satisfactory resolution of the role played by matching on participation in sclf-directed plans requires better data. In general, very few other variables are significant in the participation rate specifications (and none are significant in the highly-compensated 
group). ${ }^{10}$

The second pancl of Table 6 examines contributions, repeating the same specification as shown in Table 5, but using the first-differenced dala. The frequent seminar variable is again significant for the non-highly compensated group, and it is marginally significant in the specification for all employees. The only other significant coefficients (at conventional levels) are the occasional seminar variable (for $\mathrm{HC}$ employees) and the unionization variable (for all cmployees and $\mathrm{HC}$ employees).

\section{Robustness}

The results presented in the previous sections depict a strong correlation between frequent seminars and $40 \mathrm{I}(\mathrm{k})$ activity, espccially among NHC cmployces. In order to verify the robustness of these results we examine the sensitivity of our results to a different method for measuring the intensity of education. We also employ several alternate estimation techniques: median, robust, and Tobit regression.

In the previous section, there were certain cases (most notably differenced specifications for participation) where the effects of frequent seminars were only marginally significant. This may occur, at least in part, because we are asking the data to identify too many parameters. In these same cases, the point estimates for the cliccls of occasional scminars arc roughly half of the corresponding point estimates for the effects of frequent seminars (sce table 6). It is therefore natural to consider an alternate specification based on a scalar measure of cducational intensity that allows us to summarize the effects of education through a single parameter. Instead of constructing dummy variables based on the frequency of educational offerings, we simply measure frequency on a scale of zero to three, depending on whether education is offered never, rarely, sometimes, or often. This specilication forces the effects of an increase in the frequency of education to be the same when moving from each qualitative response to the next. That is, it assumes that an increase

\footnotetext{
${ }^{10}$ In table 6, the occasional provision of summary plan descriptions appears to have a positive and significant effect on participation. However, this result is apparently driven by outliers; it vanishes when more robust estimation techniques are applied (as in the next section).
} 
from never to rarcly has the same effect on participation and contribution rates as an increase from rarely to sometimes or sometimcs to often. Whilc restrictive, it is more parsimonious than our original procedure, and is generally not rejected by the data.

We estimate median and robust regression models to reduce the potential influence of outlying observations. ${ }^{11}$ The standard errors reported for the median and robust regressions (as well as for the Tobit estimates) using the pooled data are not adjusted for the fact that the same firm may appear in the pooled sample twice. As the standard errors were similar with and without this correction in the OLS specifications shown in Table 5, we do not view this as a major shortcoming.

We use Tobit regressions to account for right and left censoring of participation rates at 0 and 100 percent. While censoring occurs in the data for all three employee categories, it is particularly prevalent for HC employees. In the pooled data. the participation rate equals 100 percent for all employees in 29 of 1027 observations and for NHC cmployees in 27 observations out of 805 . For $\mathrm{HC}$ employees this number jumps to 267 of 824 observations, or approximately 30 percent of the sample. Left-censored observation (i.e., those for which the participation rate is 0 percent) are not nearly as prevalent. There are no such observations for all employees and NHC employees, and only 12 cases for $\mathrm{HC}$ employees. We estimate Tobit models only for participation rates using pooled cross-scctional data. While censoring is also present in the differenced versions of these models. as well as in models for contribution rates (both because of the censoring of participation and because of limits on contributions), the Tobit model is inappropriate in these contexts.

We report the cocfficients of the seminar variables for these alternate specifications in Table 7 and Table 8. We omit the coefficients of other explanatory variables to conserve space. Each of these specifications employs the same additional covariates as the earlier OLS regressions; results for these other covariates are similar to those reported in previous subsections and are available on request.

\footnotetext{
"Median regession accomplishes this by minimizing the sum of the absolute values of the residuals rather than the sum of squared residuals. Robust regression lirst eliminates gross outliers and then performs Huber iterations followed by biweight iterations in order to weight observations more evenly in the loss function.
} 
i. An alternative measwre of seminar intensity

For every specification contained in tables 5,6,7, and 8 , we present results based on an analogous specification in which we use a single scalar measure of educational intensity, as described at the outset of this section. The resulling coeflicients for seminars are presented in tables 7 and 8 under columns labeled "intensity."

Generally speaking, for specifications involving pooled (as opposed to differenced) data, the magnitudes and statistical precision of educational eflects are similar to the results obtained using separate dummies for frequent and occasional seminars. However, the use of the seminar intensity variable sharpens the estimates considerably for the differenced data. For example, in the first column of table 6 (which concerns participation rates), the coefficient on frequent seminars for NHC employees is only significant at the 7 percent level. However, its magnitude is also roughly twice that of the occasional seminar variable, which suggests that use of the intensity variable may be appropriate. Indeed, as indicated in the first column of table 7 , the estimaled coefficient for the intensity variable in an analogous specification is statistically significant at the I percent level. A similar observation applies to differenced estimates of participation rates for all employees. In general. with differenced data, the effects of seminars on participation (table 7) and contributions (table 8 ) are found to be significant at a higher level of confidence when a single measure of educational intensity is used.

\section{ii. Median and robust regression: robustness of participation results}

We present median and robust regression results for participation in the middle sections of Table 7 . In many respects, these results are qualitatively similar to the OLS estimates. In the pooled data, the coefficient on frequent seminars for NHC employees drops from 11.5 in the OLS specification to 9.9 in the median and 11.2 in the robust regression. Howcrer, both of these coefficients remain significant at the I percent level. The coefficients of occasional scminars for NHC cmployees rise relative to OLS, but still fail to achieve statistical significance at conventional levels. There is no indication that seminars - even frequent ones - 
have a significant impact on the participation rates of $\mathrm{HC}$ employees. It is therefore possible that the effects of frequent seminars on HC cmployees measured in OLS regressions (as well as in the Tobit regressions reported later) reflect the influence of outliers. For HC employees, the unexpected negative coefficient (from OLS) on occasional seminars is reduced to a number much closer to zero in both the median and robust regressions. Finally, the effect of frequent seminars on participation rates for all employees is a bit weaker in median regression and robust regressions than for OLS; however, the effect of occasional seminars, though still smaller than the effect of lrequent seminars, now achieves conventional levels of statistical significance For the differenced data. both the median and robust regressions reduce the size of the coefficients for frequent seminars, but also increase the precision with which they are measured. The coefficient on frequent seminars for NHC cmployees drops from 12.1 in the OLS specification to 7.4 in the median and 8.6 in the robust regression. However, while the OLS coefficient was only significant at the 7 percent level, the median regression coeflicient is significant at the 2 percent level and the robust regression at the 5 percent level. Notably, while the effect of occasional seminars on NHC participation was not significant in OLS estimates with differenced data, it is significant (and substantial) in both median and robust regression estimates. Median and robust regressions also yield more precise coefficients for $\mathrm{HC}$ employees. For the median regression in particular, the effect is statistically significant, even though its magnitude is small. We suspect that this result is attributable to the nature of the distribution of the differenced HC participation rates. Many of the participation rates for HC cmployces are at or near 100 percent for both 1993 and 1994; consequently, more than 30 percent of the firms in the sample experience no change in the measured participation rate of HC employees between 1993 and 1994. Since the median change is zero, and since there are so many zeros, it is not surprising that our explanatory variables are found to have very little effect on the median, or that this finding is precise. The effect of frequent seminars on participation rates disappears in the median and robust regression estimates of the differenced specification for all employees; however, the impact of occasional seminars emerges as significant. Finally, as noted earlier the use of the intensity variable also enhances the 
statistical significance of the educational effect on NHC participation rates in both the median and robust regression estimates that make use of differenced data.

iii. Median and robust regression: robustness of the contribution results

The median and robust regression results for contribution rates appear in Table 8 . The top panel contains results for regressions with pooled data. The results for the robust regressions are qualitatively similar to the earlicr OLS estimation, with a slight drop in the coefficients on frequent seminars. For example, in the specification for NHC employees, this coefficient drops from 0.81 to 0.69 . The statistical significance of the estimates is comparable to that of the OLS coefficients, with the coefficient on frequent seminars for NHC employecs remaining significant at the l percent significance level. The effect of occasional seminars is also statistically significant in the specification for all employees. In contrast, the median regression results for contribution rates are weaker than the OLS and robust regression results. While the signs of the coefficients are the same. magnitudes are generally lower, and no single seminar dummy achieves statistical significance al conventional levels. However, the seminar intensity variables approaches statistical significance at the 95 percent confidence level in the specifications for NHC and all employees.

The bottom panel of table 8 presents median and robust regression results for contribution rates using differenced data. The effect of frequent seminars on NHC contribution rates is still reasonably strong, and similar to that obtained using OLS. None of the other seminar dummies depicted in this lower panel achieves statistical significance. The estimated effect of frequent seminars on the HC contribution rate is actually negative and fairly large in magnitude, but not very precise. However, as with the previous specifications, when the seminar intensity variable is used, median and robust regression estimates of the seminar effect for NHC employees are similar in magnitude to the OLS results and statistically significant at the usual levels of confidence.

iv. Tobit regression reswlts

Tobit results for rates of participation appear in the last section of Table 7. The coefficients for both 
frequent and occasional seminars increase in size (relative to OLS) for all three employee groups. The most dramatic change occurs in the coefficient for frequent seminars for $\mathrm{HC}$ employees, which increases from 6.4 to 10.5 . This result is not surprising given the fact that more than 30 percent of the HC observations are right-censored. Although precision is somewhat lower for the Tobit estimates than for OLS, the coefficient of frequent seminars for NHC employecs remains significant at the 1 percent level, and the coefficient for $\mathrm{HC}$ employees remains significant at the 5 pcrcent level. These results suggest that censoring causes a downward bias in the OLS coefficients, and that $\mathrm{HC}$ and NHC employees respond to education more similarly than the OLS results appear to indicate. Again, using the seminar intensity variable results in more precisely estimated effects

\section{Conclusions}

In this paper, we have cxamined the effects of employer-based retirement education on $40 \mathrm{l}(\mathrm{k})$ activity using firm-level data. Our results indicate that retirement seminars are generally associated with significantly higher rates of participation and contributions, at least when the frequency of these offerings is high. The effect appears to be particularly strong for non-highly compensated employees. Our findings reflect both cross-sectional and longitudinal patterns in the data, and they are robust with respect to a variety of estimation techniques.

The current paper is complementary to Bernheim and Garrett (1996) who use household survey data to investigate the effects of education on total saving, both inside and outside of pension plans. However, since their data are cross-sectional, they are forced to make indirect inferences concerning the probable direction of biases that might result from the inevitable failure to control for unobserved individual effects. With household survey data, it is also difficult to distinguish between the effects of education on behavior, and the effects of education on the way that individuals report behavior. In contrast, the employer survey data used here allow us to examine both cross-sectional and longitudinal patterns; moreover, there is relatively little risk 
that the education of employees would affect the way that employers report rates of participation and contributions. The tradeoff, of course, is that employer survey data provide no information on assets held outside of pension plans, and therefore do not permit us to investigate whether increased participation and contributions reflect new saving, rather than asset reshuffling.

Taken together, the current paper and that of Bernheim and Garrett (1996) suggest that financial education in the workplace can exert a strong influence on personal financial decisions. More generally, these studies raise the possibility that the enhancement of decision-making skills (as opposed to labor market skills) may constitute a significant economic return to education. 


\section{References}

A. Foster Higgins \& Co., Inc. Survey of Employee Savings Plans. 1994, Report 2: Plan Participation and Discrimination Testing. Princelon, NJ: A. Foster Higgins \& Co., Inc., 1994.

Andrews, Emily S., "The Growth and Distribution of 40l(k) Plans," in J Turner and D. Beller, eds., Trends in Pensions 1992, Washington, D. C., U.S. Department of Labor, 1992.

Becker, Gary S., Human Capital and the Personal Distribution of Income, Ann Arbor: University of Michigan Press: 1967.

Berg, Olena, "DOL to Launch Savings and Pension Education Campaign," EBRI Notes, June 1995, p. 2.

Bernheim, B. Douglas, The Vanishing Nest Egg: Reflections on Saving in America, New York: Priority Press, 1991.

Bernheim, B. Douglas, "Personal Saving, Information, and Economic Literacy: New Directions for Public Policy," in Tax Policy for Economic Growth in the 1990s, Washington, DC: American Council for Capital Formation, 1994a, 53-78.

Bernheim, B. Douglas, "Comments and Discussion," Brookings Papers on Economic Activity (1), 1994b, 152-166.

Bernheim, B. Douglas, "Do Households Appreciate Their Financial Vulnerabilities? An Analysis of Actions, Perceptions, and Public Policy," Tax Policy and Economic Growth, Washington, DC: American Council for Capital Formation, 1995a, pp. 1-30.

Bernheim, B. Douglas, "The Merrill Lynch Baby Boom Retirement Index: Update '95," mimeo, 1995b.

Bernheim, B. Douglas, "Rethinking Saving Incentives," in Alan Auerbach (ed.), Fiscal Policy: Lessons from Economic Research, Cambridge, MA: MIT Press, 1996a, forthcoming.

Bernheim, B. Douglas, "Financial Illiteracy, Education, and Retirement Saving," in Living with Defined Contribution Plans, Pension Research Council, the Wharton School, University of Pennsylvania, 1996b, forthcoming.

Bernheim, B. Douglas and Daniel Garrett, "The Determinants and Consequences of Financial Education in the Workplace: Evidence from a Survey of Households," mimeo, Stanford University, March 1996.

Bernheim, B. Douglas and John Karl Scholz, "Private Saving and Public Policy," Tax Policy and the Economy 7, 1993, 73-110.

Borleis, Melvin W. and Kimberly K. Wedell, "How to spark employee interest with employer matching contributions," Profit Sharing, January 1994, pp. 7-16.

Card, David, "Earnings, Schooling, and Ability Revisited," Research in Labor Economics 14, 1995, pp. 2348. 
Central Council for Savings Promotion, Savings and Savings Promotion Movement in Japan, Tokyo: Bank of Japan, 1981.

Congressional Budget Ottice, Baby Boomers in Retirement: An Early Perspective, September 1993.

Employee Benefit Research Institute, Rerirement Confidence in America: Getting Ready for Tomorrow, EBRI Special Report SR-27, Issue Brief Number 156, December 1994.

Employee Benefit Rescarch Institute, "Can We Save Enough to Retire? Participant Education in Defined Contribution Plans," EBRI Issue Brief, no. 160, April 1995.

Engen, Eric M., William G. Gale, and John Karl Scholz, "Do Saving Incentives Work?" Brookings Papers on Economic Activity (1), 1994, 85-151.

Garrett, Daniel M., "The Effects of Nondiscrimination Rules on 401(k) Contributions," mimeo, Stanford University, 1995.

Geisel, Jerry, "Communication yields success for XTRA 40 I(k)," Business Insurance, April 10, 1995, p. 3

Hubbard, R. Glenn, Jonathan Skinner, and Stephen P. Zeldes, "Precautionary Saving and Social Insurance," Journal of Political Economy, 103(2), April 1995, 360-399.

Kusko, Andrea, James M. Poterba, and David W. Wilcox, "Employee Decisions With Respect to 401 (k) Plans: Evidence from Individual Level Data," Working Paper No. 4635, National Bureau of Economic Research, 1994.

Papke, Leslic E., "Participation in and Contributions to 401(k) Plans: Evidence from Plan Data," Journal of Human Resources 30(2). Spring 1995.

Papke, Leslie, Mitchell Pctersen. and James M. Polerba, "Did 40 l(k) Plans Replace Other Employer Provided Pensions?" Working Paper No. 4501, National Bureau of Economic Research, October 1993.

Poterba, James M., Steven F. Venti, and David A. Wise, "401(k) Plans and Tax-Deferred Saving," in David A. Wise, ed., Studies in the Economics of Aging, Chicago: University of Chicago Press, 1994.

Scott, Jason, “The Compensation Value of 401 (k) Pension Plans," mimeo, Stanford University, 1994.

Sheffrin, Hersh M., and Richard H. Thaler. "The Behavioral Life-Cycle Hypothesis," Economic Inquiry 26(4), 1988, 609-43. 
Table 1: Mean and Median 401(k) Participation and Contrihution Rates

\begin{tabular}{|c|c|c|c|c|c|}
\hline & & Observations & Median & Mean & $\begin{array}{c}\text { Employment-Weighted } \\
\text { Mean }\end{array}$ \\
\hline \multicolumn{6}{|l|}{ 1993: } \\
\hline \multirow[t]{3}{*}{ Participation Rates } & NHC & 415 & 60.9 & 59.44 & 59.66 \\
\hline & $\mathrm{HC}$ & 422 & 92.5 & 82.59 & 82.34 \\
\hline & All & 530 & 70.0 & 63.08 & 64.32 \\
\hline \multirow[t]{3}{*}{ Conditional Contribution Rates } & $\mathrm{NHC}$ & 395 & 5.0 & 4.96 & 4.72 \\
\hline & $\mathrm{HC}$ & 398 & 6.0 & 6.75 & 6.09 \\
\hline & All & 457 & 5.0 & 5.15 & 5.14 \\
\hline \multirow[t]{3}{*}{ Unconditional Contribution Rates } & NHC & 349 & 2.8 & 3.06 & 2.91 \\
\hline & $\mathrm{HC}$ & 352 & 5.7 & 5.79 & 5.16 \\
\hline & All & 437 & 3.4 & 3.39 & 3.46 \\
\hline \multicolumn{6}{|l|}{ 1994: } \\
\hline \multirow[t]{3}{*}{ Participation Rates } & $\mathrm{NHC}$ & 392 & 60.0 & 57.68 & 55.18 \\
\hline & $\mathrm{HC}$ & 404 & 92.0 & 78.56 & 82.69 \\
\hline & All & 500 & 70.0 & 61.23 & 60.77 \\
\hline \multirow[t]{3}{*}{ Conditional Contribution Rates } & $\mathrm{NHC}$ & 357 & 5.0 & 4.86 & 4.84 \\
\hline & $\mathrm{HC}$ & 359 & 6.0 & 6.66 & 6.05 \\
\hline & All & 412 & 5.0 & 5.34 & 5.32 \\
\hline \multirow[t]{3}{*}{ Unconditional Contribution Rates } & $\mathrm{NHC}$ & 311 & 2.6 & 2.94 & 2.79 \\
\hline & $\mathrm{HC}$ & 317 & 5.4 & 5.44 & 5.07 \\
\hline & All & 393 & 3.3 & 3.41 & 3.55 \\
\hline
\end{tabular}

Source: Derived from KPMG Peat Marwick's Retirement Benefits in the 1990s: 1993 and 1994 Survey Data. 
Table 2: The Effect of Retirement Plan Type on Education - All Companies

\begin{tabular}{|c|c|c|c|c|c|}
\hline \multirow[t]{2}{*}{ 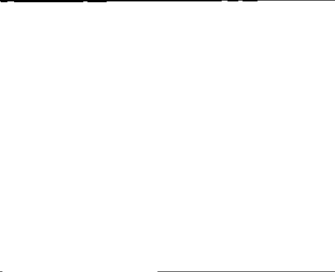 } & \multicolumn{5}{|c|}{ Dependent Variable } \\
\hline & $\begin{array}{l}\text { Seminars } \\
\text { for All } \\
\text { Einployees }\end{array}$ & $\begin{array}{l}\text { Seminars for } \\
\text { Employees } \\
\text { Over } 50\end{array}$ & $\begin{array}{c}\text { Seminars for } \\
\text { Employees } \\
\text { Near Retirement }\end{array}$ & $\begin{array}{l}\text { Summary } \\
\text { Plan } \\
\text { Descriptions }\end{array}$ & $\begin{array}{l}\text { Newsletters or } \\
\text { Periodicals }\end{array}$ \\
\hline Only $401(\mathrm{k})$ Plan & $\begin{array}{l}0.251 \\
(.129)\end{array}$ & $\begin{array}{l}-0.221 \\
(.141)\end{array}$ & $\begin{array}{l}-0.343 \\
(.143)\end{array}$ & $\begin{array}{l}0.727 \\
(.134)\end{array}$ & $\begin{array}{l}0.464 \\
(.129)\end{array}$ \\
\hline Only 403(b) Plan & $\begin{array}{l}0.759 \\
(.204)\end{array}$ & $\begin{array}{l}0.503 \\
(.205)\end{array}$ & $\begin{array}{l}0.325 \\
(.207)\end{array}$ & $\begin{array}{l}0.185 \\
(.202)\end{array}$ & $\begin{array}{l}0.104 \\
(.200)\end{array}$ \\
\hline Only Another Plan & $\begin{array}{l}0.107 \\
(.151)\end{array}$ & $\begin{array}{l}-0.177 \\
(.165)\end{array}$ & $\begin{array}{l}-0.092 \\
(.162)\end{array}$ & $\begin{array}{l}0.059 \\
(.148)\end{array}$ & $\begin{array}{l}-0.210 \\
(.148)\end{array}$ \\
\hline Two or More Plans & $\begin{array}{l}0.326 \\
(.113)\end{array}$ & $\begin{array}{l}0.34 \\
(.119)\end{array}$ & $\begin{array}{l}0.274 \\
(.119)\end{array}$ & $\begin{array}{l}0.554 \\
(.112)\end{array}$ & $\begin{array}{l}0.484 \\
(.111)\end{array}$ \\
\hline Total Employment* & $\begin{array}{l}0.255 \\
(.181)\end{array}$ & $\begin{array}{l}0.352 \\
(.141)\end{array}$ & $\begin{array}{l}0.322 \\
(.141)\end{array}$ & $\begin{array}{l}-0.174 \\
(.169)\end{array}$ & $\begin{array}{l}0.204 \\
(.147)\end{array}$ \\
\hline $\begin{array}{l}\text { Fraction of Employees } \\
\text { Covered by Plans }\end{array}$ & $\begin{array}{l}0.0032 \\
(.0012)\end{array}$ & $\begin{array}{l}0.0047 \\
(.0012)\end{array}$ & $\begin{array}{l}0.0041 \\
(.0012)\end{array}$ & $\begin{array}{l}-0.0033 \\
(.0013)\end{array}$ & $\begin{array}{l}0.0001 \\
(.0012)\end{array}$ \\
\hline 1994 Dummy & $\begin{array}{l}0.093 \\
(.060)\end{array}$ & $\begin{array}{l}-0.050 \\
(.063)\end{array}$ & $\begin{array}{l}0.003 \\
(.064)\end{array}$ & $\begin{array}{l}-0.134 \\
(.065)\end{array}$ & $\begin{array}{l}0.077 \\
(.063)\end{array}$ \\
\hline Intercept & $\begin{array}{l}-0.647 \\
(.142)\end{array}$ & $\begin{array}{l}-0.999 \\
(.151)\end{array}$ & $\begin{array}{l}-0.951 \\
(.151)\end{array}$ & $\begin{array}{l}0.431 \\
(.145)\end{array}$ & $\begin{array}{l}0.016 \\
(.141)\end{array}$ \\
\hline $\mathbf{N}$ & 1778 & 1773 & 1773 & 1771 & 1778 \\
\hline
\end{tabular}

*Coefficients for Total Employment are multiplied by $10^{5}$.

Excluded Variable is Only Defined Benetits Plan.

Standard errors are in parentheses.

Source: Derived froin KPMG Peat Marwick's Retirement Benefits in the 1990s: 1993 and 1994 Survey Data. 
Table 3: The Effect of Retirement Plan Type on Education - Companies with 401(k) Plans

Dependent Variable

\begin{tabular}{|c|c|c|c|c|c|}
\hline & $\begin{array}{l}\text { Seminars } \\
\text { for All } \\
\text { Eınployees }\end{array}$ & $\begin{array}{l}\text { Seminars for } \\
\text { Employees } \\
\text { Over } 50\end{array}$ & $\begin{array}{l}\text { Seminars for } \\
\text { Employees } \\
\text { Near Retirement }\end{array}$ & $\begin{array}{l}\text { Summary } \\
\text { Plan } \\
\text { Descriptions }\end{array}$ & $\begin{array}{l}\text { Newsletters or } \\
\text { Periodicals }\end{array}$ \\
\hline Defined Benefits & 0.065 & 0.627 & 0.652 & -0.090 & 0.072 \\
\hline Plan & $(.106)$ & $(.115)$ & $(.118)$ & $(.116)$ & $(.111)$ \\
\hline Other Retirement Plan & -0.009 & 0.258 & 0.343 & -0.020 & 0.082 \\
\hline No DB Plan & $(.109)$ & $(.120)$ & $(.121)$ & $(.118)$ & $(.113)$ \\
\hline Total Employment* & $\begin{array}{l}0.491 \\
(.264)\end{array}$ & $\begin{array}{l}0.754 \\
(.292)\end{array}$ & $\begin{array}{l}0.702 \\
(.285)\end{array}$ & $\begin{array}{l}-0.389 \\
(.267)\end{array}$ & $\begin{array}{l}0.397 \\
(.332)\end{array}$ \\
\hline $\begin{array}{l}\text { Fraction of Employees } \\
\text { Covered by Plans }\end{array}$ & $\begin{array}{l}0.0019 \\
(.0016)\end{array}$ & $\begin{array}{l}0.0034 \\
(.0017)\end{array}$ & $\begin{array}{l}-0.0029 \\
(.0017)\end{array}$ & $\begin{array}{l}-0.0049 \\
(.0017)\end{array}$ & $\begin{array}{l}-0.0017 \\
(.0016)\end{array}$ \\
\hline Union Eligibility & $\begin{array}{l}-0.038 \\
(.093)\end{array}$ & $\begin{array}{l}0.016 \\
(.095)\end{array}$ & $\begin{array}{l}0.034 \\
(.096)\end{array}$ & $\begin{array}{l}0.056 \\
(.095)\end{array}$ & $\begin{array}{l}0.140 \\
(.096)\end{array}$ \\
\hline Employer Match & $\begin{array}{l}-0.165 \\
(.111)\end{array}$ & $\begin{array}{l}-0.042 \\
(.111)\end{array}$ & $\begin{array}{l}-0.123 \\
(.110)\end{array}$ & $\begin{array}{l}0.203 \\
(.119)\end{array}$ & $\begin{array}{l}0.054 \\
(.111)\end{array}$ \\
\hline Number of Options & $\begin{array}{l}0.166 \\
(.036)\end{array}$ & $\begin{array}{l}0.179 \\
(.039)\end{array}$ & $\begin{array}{l}0.186 \\
(.040)\end{array}$ & $\begin{array}{l}0.132 \\
(.041)\end{array}$ & $\begin{array}{l}0.179 \\
(.038)\end{array}$ \\
\hline Loans Permitted & $\begin{array}{l}0.213 \\
(.090)\end{array}$ & $\begin{array}{l}0.147 \\
(.095)\end{array}$ & $\begin{array}{l}0.120 \\
(.093)\end{array}$ & $\begin{array}{l}0.013 \\
(.095)\end{array}$ & $\begin{array}{l}-0.034 \\
(.091)\end{array}$ \\
\hline 1994 Dummy & $\begin{array}{l}-0.015 \\
(.072)\end{array}$ & $\begin{array}{l}-0.216 \\
(.080)\end{array}$ & $\begin{array}{l}-0.203 \\
(.080)\end{array}$ & $\begin{array}{l}-0.229 \\
(.084)\end{array}$ & $\begin{array}{l}-0.026 \\
(.081)\end{array}$ \\
\hline Intercept & $\begin{array}{l}-0.773 \\
(.173)\end{array}$ & $\begin{array}{l}-1.729 \\
(.188)\end{array}$ & $\begin{array}{l}-1.724 \\
(.190)\end{array}$ & $\begin{array}{l}0.737 \\
(.188)\end{array}$ & $\begin{array}{l}0.044 \\
(.176)\end{array}$ \\
\hline $\mathrm{N}$ & 1170 & 1169 & 1170 & 1162 & 1169 \\
\hline
\end{tabular}

*Coefficients for Total Einployinent are multiplied by $10^{5}$; coefficients for 1994 Dummy are multiplied by $10^{4}$.

Excluded Variable is Only $40 \mathrm{l}(\mathrm{k})$ Plan.

Standard errors are in parentheses.

Source: Derived from KPMG Peat Marwick's Rerivement Benefits in the 1990s: 1993 and 1994 Survey Data. 
Dependent Variable

\begin{tabular}{|c|c|c|c|c|c|}
\hline & $\begin{array}{l}\text { Seininars } \\
\text { for All } \\
\text { Employees }\end{array}$ & $\begin{array}{l}\text { Seininars for } \\
\text { Employees } \\
\text { Over } 50\end{array}$ & $\begin{array}{l}\text { Seminars for } \\
\text { Employees } \\
\text { Near Retirement }\end{array}$ & $\begin{array}{l}\text { Summary } \\
\text { Plan } \\
\text { Descriptions }\end{array}$ & $\begin{array}{l}\text { Newsletters or } \\
\text { Periodicals }\end{array}$ \\
\hline $\begin{array}{l}\text { NHC Participation } \\
1993\end{array}$ & $\begin{array}{l}-0.0084 \\
(.0038)\end{array}$ & $\begin{array}{l}-0.0058 \\
(.0031)\end{array}$ & $\begin{array}{l}-0.0059 \\
(.0032)\end{array}$ & $\begin{array}{l}-0.0013 \\
(.0047)\end{array}$ & $\begin{array}{l}0.0020 \\
(.0046)\end{array}$ \\
\hline $\begin{array}{l}\text { HC Participation } \\
1993\end{array}$ & $\begin{array}{l}-0.0018 \\
(.0035)\end{array}$ & $\begin{array}{l}-0.0045 \\
(.0028)\end{array}$ & $\begin{array}{l}-0.0001 \\
(.0029)\end{array}$ & $\begin{array}{l}-0.0043 \\
(.0044)\end{array}$ & $\begin{array}{l}-0.0057 \\
(.0046)\end{array}$ \\
\hline $\begin{array}{l}\text { Fraction of Einployees } \\
\text { Covered by Plan }\end{array}$ & $\begin{array}{l}0.0044 \\
(.0030)\end{array}$ & $\begin{array}{l}0.0031 \\
(.0024)\end{array}$ & $\begin{array}{l}0.0012 \\
(.0025)\end{array}$ & $\begin{array}{l}0.0041 \\
(.0038)\end{array}$ & $\begin{array}{l}0.0004 \\
(.0037)\end{array}$ \\
\hline $\begin{array}{l}\text { Total Employment* } \\
1993\end{array}$ & $\begin{array}{l}0.091 \\
(0.504)\end{array}$ & $\begin{array}{l}-0.959 \\
(0.406)\end{array}$ & $\begin{array}{l}-0.448 \\
(0.420)\end{array}$ & $\begin{array}{l}-0.338 \\
(0.621)\end{array}$ & $\begin{array}{l}0.165 \\
(.609)\end{array}$ \\
\hline $\begin{array}{l}\text { Union Eligibility } \\
1993\end{array}$ & $\begin{array}{l}-0.083 \\
(.182)\end{array}$ & $\begin{array}{l}-0.282 \\
(.148)\end{array}$ & $\begin{array}{l}-0.196 \\
.(.152)\end{array}$ & $\begin{array}{l}-0.501 \\
(.224)\end{array}$ & $\begin{array}{l}-0.057 \\
(.220)\end{array}$ \\
\hline $\begin{array}{l}\text { Employer Match } \\
1993\end{array}$ & $\begin{array}{l}0.207 \\
(.227)\end{array}$ & $\begin{array}{l}-0.058 \\
(.182)\end{array}$ & $\begin{array}{l}-0.030 \\
(.189)\end{array}$ & $\begin{array}{l}0.251 \\
(.280)\end{array}$ & $\begin{array}{l}0.412 \\
(.274)\end{array}$ \\
\hline $\begin{array}{l}\text { Defined Benefits } \\
\text { Plan - } 1993\end{array}$ & $\begin{array}{l}-0.339 \\
(.197)\end{array}$ & $\begin{array}{l}-0.082 \\
(.159)\end{array}$ & $\begin{array}{l}-0.069 \\
(.164)\end{array}$ & $\begin{array}{l}-0.183 \\
(.243)\end{array}$ & $\begin{array}{l}-0.285 \\
(.238)\end{array}$ \\
\hline $\begin{array}{l}\text { Other Pension Plan } \\
\text { No DB Plan - } 1993\end{array}$ & $\begin{array}{l}-0.094 \\
(.208)\end{array}$ & $\begin{array}{l}-0.184 \\
(.167)\end{array}$ & $\begin{array}{l}-0.069 \\
(.173)\end{array}$ & $\begin{array}{l}0.107 \\
(.256)\end{array}$ & $\begin{array}{l}-0.180 \\
(.251)\end{array}$ \\
\hline $\begin{array}{l}\text { Loans Permitted } \\
1993\end{array}$ & $\begin{array}{l}0.059 \\
(.169)\end{array}$ & $\begin{array}{l}-0.144 \\
(.136)\end{array}$ & $\begin{array}{l}-0.005 \\
(.141)\end{array}$ & $\begin{array}{l}-0.015 \\
(.209)\end{array}$ & $\begin{array}{l}-0.045 \\
(.204)\end{array}$ \\
\hline $\begin{array}{l}\text { Investment Options } \\
1993\end{array}$ & $\begin{array}{l}0.058 \\
(.070)\end{array}$ & $\begin{array}{l}0.071 \\
(.057)\end{array}$ & $\begin{array}{l}0.027 \\
(.059)\end{array}$ & $\begin{array}{l}0.003 \\
(.087)\end{array}$ & $\begin{array}{l}0.079 \\
(.085)\end{array}$ \\
\hline Intercept & $\begin{array}{l}0.168 \\
(.416)\end{array}$ & $\begin{array}{l}0.579 \\
(.344)\end{array}$ & $\begin{array}{l}0.201 \\
(.346)\end{array}$ & $\begin{array}{l}-0.049 \\
(.519)\end{array}$ & $\begin{array}{l}-0.013 \\
(.502)\end{array}$ \\
\hline $\mathrm{N}$ & 244 & 243 & 244 & 243 & 244 \\
\hline
\end{tabular}

*Coefficients for Total Employment are multiplied by $10^{9}$.

All dependent variables are first differenced.

Standard errors are in parentheses.

Source: Derived from KPMG Peat Marwick's Retirement Benefits in the 1990s: 1993 and 1994 Survey Data. 


\begin{tabular}{|c|c|c|c|c|c|c|}
\hline & \multicolumn{6}{|c|}{ Dependent Variable } \\
\hline & \multicolumn{3}{|c|}{ Participation Rates } & \multicolumn{3}{|c|}{ Contribution Rates } \\
\hline & $\overline{\mathrm{NHC}}$ & $\mathrm{HC}$ & All & $\mathrm{NHC}$ & $\mathrm{HC}$ & All \\
\hline $\begin{array}{l}\text { Seminars } \\
\text { Often }\end{array}$ & $\begin{array}{l}11.52 \\
(3.00)\end{array}$ & $\begin{array}{l}6.37 \\
(2.94)\end{array}$ & $\begin{array}{l}8.17 \\
(2.46)\end{array}$ & $\begin{array}{l}0.809 \\
(.291)\end{array}$ & $\begin{array}{l}0.342 \\
(.417)\end{array}$ & $\begin{array}{l}0.677 \\
(.240)\end{array}$ \\
\hline $\begin{array}{l}\text { Seminars } \\
\text { Sometimes or Rarely }\end{array}$ & $\begin{array}{l}1.74 \\
(2.07)\end{array}$ & $\begin{array}{l}-2.98 \\
(2.37)\end{array}$ & $\begin{array}{l}1.43 \\
(1.75)\end{array}$ & $\begin{array}{l}0.252 \\
(.171)\end{array}$ & $\begin{array}{l}0.077 \\
(.261)\end{array}$ & $\begin{array}{l}0.232 \\
(.142)\end{array}$ \\
\hline $\begin{array}{l}\text { Newsletters } \\
\text { Often }\end{array}$ & $\begin{array}{l}-0.58 \\
(2.72)\end{array}$ & $\begin{array}{l}1.09 \\
(3.00)\end{array}$ & $\begin{array}{l}-2.30 \\
(2.23)\end{array}$ & $\begin{array}{l}0.183 \\
(.211)\end{array}$ & $\begin{array}{l}0.149 \\
(.380)\end{array}$ & $\begin{array}{l}-0.120 \\
(.186)\end{array}$ \\
\hline $\begin{array}{l}\text { Newsletters } \\
\text { Sometimes or Rarely }\end{array}$ & $\begin{array}{l}-0.91 \\
(2.63)\end{array}$ & $\begin{array}{l}0.01 \\
(2.81)\end{array}$ & $\begin{array}{l}-0.83 \\
(2.12)\end{array}$ & $\begin{array}{l}-0.088 \\
(.210)\end{array}$ & $\begin{array}{l}-0.353 \\
(.350)\end{array}$ & $\begin{array}{r}-0.248 \\
(.183)\end{array}$ \\
\hline $\begin{array}{l}\text { Plan Descriptions } \\
\text { Often }\end{array}$ & $\begin{array}{l}0.35 \\
(2.79)\end{array}$ & $\begin{array}{l}-1.66 \\
(3.16)\end{array}$ & $\begin{array}{l}2.17 \\
(2.24)\end{array}$ & $\begin{array}{l}-0.084 \\
(.196)\end{array}$ & $\begin{array}{l}0.024 \\
(.366)\end{array}$ & $\begin{array}{l}-0.137 \\
(.182)\end{array}$ \\
\hline $\begin{array}{l}\text { Plan Descriptions } \\
\text { Sometimes or Rarely }\end{array}$ & $\begin{array}{l}2.16 \\
(2.83)\end{array}$ & $\begin{array}{l}-1.00 \\
(3.07)\end{array}$ & $\begin{array}{l}1.98 \\
(2.32)\end{array}$ & $\begin{array}{l}0.282 \\
(.220)\end{array}$ & $\begin{array}{l}-0.274 \\
(.347)\end{array}$ & $\begin{array}{l}0.007 \\
(.197)\end{array}$ \\
\hline Employer Match & $\begin{array}{l}14.59 \\
(2.55)\end{array}$ & $\begin{array}{l}16.94 \\
(3.17)\end{array}$ & $\begin{array}{l}17.27 \\
(2.04)\end{array}$ & $\begin{array}{l}0.389 \\
(.238)\end{array}$ & $\begin{array}{l}0.732 \\
(.413)\end{array}$ & $\begin{array}{l}0.566 \\
(.205)\end{array}$ \\
\hline Loans Permitted & $\begin{array}{l}-1.42 \\
(2.09)\end{array}$ & $\begin{array}{l}-2.34 \\
(2.20)\end{array}$ & $\begin{array}{l}1.78 \\
(1.74)\end{array}$ & $\begin{array}{l}0.076 \\
(.159)\end{array}$ & $\begin{array}{l}0.003 \\
(.258)\end{array}$ & $\begin{array}{l}0.313 \\
(.149)\end{array}$ \\
\hline Investment Options & $\begin{array}{l}-0.158 \\
(.8 \mid 9)\end{array}$ & $\begin{array}{l}-0.237 \\
(.873)\end{array}$ & $\begin{array}{l}0.712 \\
(.720)\end{array}$ & $\begin{array}{l}0.105 \\
(.066)\end{array}$ & $\begin{array}{l}0.156 \\
(.107)\end{array}$ & $\begin{array}{l}0.099 \\
(.062)\end{array}$ \\
\hline Other Pension Plan & $\begin{array}{l}4.41 \\
(2.36)\end{array}$ & $\begin{array}{l}3.39 \\
(2.53)\end{array}$ & $\begin{array}{l}5.02 \\
(2.06)\end{array}$ & $\begin{array}{l}-0.203 \\
(.198)\end{array}$ & $\begin{array}{l}-0.306 \\
(.293)\end{array}$ & $\begin{array}{l}-0.035 \\
(.171)\end{array}$ \\
\hline Total Employment* & $\begin{array}{l}-1.78 \\
(0.64)\end{array}$ & $\begin{array}{l}-0.29 \\
(0.66)\end{array}$ & $\begin{array}{l}-1.07 \\
(0.53)\end{array}$ & $\begin{array}{l}-0.91 \\
(0.56)\end{array}$ & $\begin{array}{l}-1.71 \\
(0.59)\end{array}$ & $\begin{array}{l}-0.45 \\
(0.46)\end{array}$ \\
\hline $\begin{array}{l}\text { Fraction of Employees } \\
\text { Covered by Plan }\end{array}$ & $\begin{array}{l}0.188 \\
(.039)\end{array}$ & $\begin{array}{l}0.049 \\
(.042)\end{array}$ & $\begin{array}{l}0.236 \\
(.034)\end{array}$ & $\begin{array}{l}0.0141 \\
(.0032)\end{array}$ & $\begin{array}{l}0.0020 \\
(.0047)\end{array}$ & $\begin{array}{l}0.0153 \\
(.0029)\end{array}$ \\
\hline Union Eligibility & $\begin{array}{l}1.49 \\
(2.09)\end{array}$ & $\begin{array}{l}1.56 \\
(2.19)\end{array}$ & $\begin{array}{l}3.56 \\
(1.72)\end{array}$ & $\begin{array}{l}-0.045 \\
(.166)\end{array}$ & $\begin{array}{l}0.320 \\
(.273)\end{array}$ & $\begin{array}{l}0.171 \\
(.149)\end{array}$ \\
\hline 1994 Dummy & $\begin{array}{l}-2.30 \\
(1.82)\end{array}$ & $\begin{array}{l}-4.41 \\
(2.10)\end{array}$ & $\begin{array}{l}-3.24 \\
(1.48)\end{array}$ & $\begin{array}{l}-0.184 \\
(.145)\end{array}$ & $\begin{array}{l}-0.410 \\
(.239)\end{array}$ & $\begin{array}{l}-0.102 \\
(.124)\end{array}$ \\
\hline Intercept & $\begin{array}{l}30.90 \\
(4.47)\end{array}$ & $\begin{array}{l}65.87 \\
(5.09)\end{array}$ & $\begin{array}{l}23.16 \\
(3.64)\end{array}$ & $\begin{array}{l}1.313 \\
(.341)\end{array}$ & $\begin{array}{l}4.870 \\
(.705)\end{array}$ & $\begin{array}{l}1.386 \\
(.344)\end{array}$ \\
\hline $\mathbf{N}$ & 805 & 824 & 1027 & 658 & 667 & 827 \\
\hline
\end{tabular}

*Coefficients for Total Employment are multiplied by $10^{4}$ in the participation specifications, and $10^{5}$ in the contribution specifications.

Huber standard errors are in parentheses.

Source: Derived from KPMG Peat Marwick's Rerirement Benefits in the 1990s: 1993 and 1994 Survey Data. 
Table 6: OLS Results for Changes in Participation and Contribution Rates

\begin{tabular}{|c|c|c|c|c|c|c|}
\hline & \multicolumn{6}{|c|}{ Dependent Variable } \\
\hline & \multicolumn{3}{|c|}{ Participation Rates } & \multicolumn{3}{|c|}{ Contribution Rates } \\
\hline & $\overline{\mathrm{NHC}}$ & $\mathrm{HC}$ & All & $\mathrm{NHC}$ & $\mathrm{HC}$ & All \\
\hline $\begin{array}{l}\text { Seminars } \\
\text { Often }\end{array}$ & $\begin{array}{l}12.14 \\
(6.58)\end{array}$ & $\begin{array}{l}6.60 \\
(8.49)\end{array}$ & $\begin{array}{l}7.65 \\
(4.72)\end{array}$ & $\begin{array}{l}1.106 \\
(.513)\end{array}$ & $\begin{array}{l}-0.141 \\
(.772)\end{array}$ & $\begin{array}{l}0.408 \\
(.348)\end{array}$ \\
\hline $\begin{array}{l}\text { Seminars } \\
\text { Sometimes or Rarely }\end{array}$ & $\begin{array}{l}6.87 \\
(4.53)\end{array}$ & $\begin{array}{l}1.59 \\
(5.97)\end{array}$ & $\begin{array}{l}4.75 \\
(3.19)\end{array}$ & $\begin{array}{l}0.533 \\
(.344)\end{array}$ & $\begin{array}{l}1.044 \\
(.540)\end{array}$ & $\begin{array}{l}0.214 \\
(.235)\end{array}$ \\
\hline $\begin{array}{l}\text { Newsletters } \\
\text { Often }\end{array}$ & $\begin{array}{l}-7.02 \\
(5.35)\end{array}$ & $\begin{array}{l}-5.80 \\
(7.01)\end{array}$ & $\begin{array}{l}-2.87 \\
(3.93)\end{array}$ & $\begin{array}{l}-0.119 \\
(.410)\end{array}$ & $\begin{array}{l}-0.912 \\
(.624)\end{array}$ & $\begin{array}{r}-0.360 \\
(.292)\end{array}$ \\
\hline $\begin{array}{l}\text { Newsletters } \\
\text { Sometimes or Rarely }\end{array}$ & $\begin{array}{l}-1.41 \\
(4.85)\end{array}$ & $\begin{array}{l}-3.33 \\
(6.30)\end{array}$ & $\begin{array}{l}-1.49 \\
(3.65)\end{array}$ & $\begin{array}{l}-0.078 \\
(.384)\end{array}$ & $\begin{array}{l}-0.557 \\
(.572)\end{array}$ & $\begin{array}{r}-0.081 \\
(.279)\end{array}$ \\
\hline $\begin{array}{l}\text { Plan Descriptions } \\
\text { Often }\end{array}$ & $\begin{array}{l}6.32 \\
(5.30)\end{array}$ & $\begin{array}{l}6.62 \\
(6.69)\end{array}$ & $\begin{array}{l}3.18 \\
(3.76)\end{array}$ & $\begin{array}{l}0.240 \\
(.411)\end{array}$ & $\begin{array}{l}0.021 \\
(.597)\end{array}$ & $\begin{array}{l}-0.224 \\
(.272)\end{array}$ \\
\hline $\begin{array}{l}\text { Plan Descriptions } \\
\text { Sometimes or Rarely }\end{array}$ & $\begin{array}{l}11.34 \\
(5.49)\end{array}$ & $\begin{array}{l}11.60 \\
(6.97)\end{array}$ & $\begin{array}{l}6.29 \\
(3.80)\end{array}$ & $\begin{array}{l}0.711 \\
(.424)\end{array}$ & $\begin{array}{l}0.695 \\
(.624)\end{array}$ & $\begin{array}{l}0.217 \\
(.278)\end{array}$ \\
\hline Employer Match & $\begin{array}{l}-1.56 \\
(5.66)\end{array}$ & $\begin{array}{l}0.77 \\
(7.61)\end{array}$ & $\begin{array}{l}-0.22 \\
(4.36)\end{array}$ & $\begin{array}{l}-0.072 \\
(.457)\end{array}$ & $\begin{array}{l}0.270 \\
(.695)\end{array}$ & $\begin{array}{l}-0.016 \\
(.325)\end{array}$ \\
\hline Loans Permitted & $\begin{array}{l}1.31 \\
(7.63)\end{array}$ & $\begin{array}{l}1.30 \\
(10.52)\end{array}$ & $\begin{array}{l}2.54 \\
(5.93)\end{array}$ & $\begin{array}{l}-0.683 \\
(.617)\end{array}$ & $\begin{array}{l}-0.715 \\
(1.02)\end{array}$ & $\begin{array}{r}-0.603 \\
(.433)\end{array}$ \\
\hline Investment Options & $\begin{array}{l}2.44 \\
(1.89)\end{array}$ & $\begin{array}{l}2.76 \\
(2.50)\end{array}$ & $\begin{array}{l}0.18 \\
(1.43)\end{array}$ & $\begin{array}{l}0.300 \\
(.153)\end{array}$ & $\begin{array}{l}0.102 \\
(.226)\end{array}$ & $\begin{array}{l}0.132 \\
(.107)\end{array}$ \\
\hline Other Pension Plan & $\begin{array}{l}9.44 \\
(5.25)\end{array}$ & $\begin{array}{l}5.02 \\
(6.97)\end{array}$ & $\begin{array}{l}3.51 \\
(4.11)\end{array}$ & $\begin{array}{l}-0.002 \\
(.419)\end{array}$ & $\begin{array}{l}0.408 \\
(.629)\end{array}$ & $\begin{array}{l}0.037 \\
(.295)\end{array}$ \\
\hline Total Employment* & $\begin{array}{l}0.43 \\
(3.51)\end{array}$ & $\begin{array}{l}2.25 \\
(4.60)\end{array}$ & $\begin{array}{l}1.54 \\
(2.34)\end{array}$ & $\begin{array}{l}0.083 \\
(.261)\end{array}$ & $\begin{array}{l}-0.011 \\
(.389)\end{array}$ & $\begin{array}{l}0.030 \\
(.168)\end{array}$ \\
\hline $\begin{array}{l}\text { Fraction of Employees } \\
\text { Covered by Plan }\end{array}$ & $\begin{array}{l}0.135 \\
(.089)\end{array}$ & $\begin{array}{l}0.098 \\
(.115)\end{array}$ & $\begin{array}{l}0.078 \\
(.067)\end{array}$ & $\begin{array}{l}0.0045 \\
(.0070)\end{array}$ & $\begin{array}{l}0.0131 \\
(.0108)\end{array}$ & $\begin{array}{r}-0.0041 \\
(.0049)\end{array}$ \\
\hline Union Eligibility & $\begin{array}{l}-1.95 \\
(4.92)\end{array}$ & $\begin{array}{l}6.10 \\
(6.28)\end{array}$ & $\begin{array}{l}9.00 \\
(3.82)\end{array}$ & $\begin{array}{l}0.055 \\
(.402)\end{array}$ & $\begin{array}{l}I .465 \\
(.586)\end{array}$ & $\begin{array}{l}0.786 \\
(.272)\end{array}$ \\
\hline Intercept & $\begin{array}{l}-7.81 \\
(2.88)\end{array}$ & $\begin{array}{l}-8.55 \\
(3.89)\end{array}$ & $\begin{array}{l}-4.38 \\
(2.10)\end{array}$ & $\begin{array}{l}-0.360 \\
(.239)\end{array}$ & $\begin{array}{l}-0.557 \\
(.359)\end{array}$ & $\begin{array}{r}-0.213 \\
(.165)\end{array}$ \\
\hline $\mathrm{N}$ & 188 & 196 & 291 & 148 & 147 & 213 \\
\hline
\end{tabular}

*Coefficients for Total Employment are multiplied by $10^{4}$.

All variables, both dependent and independent, are first differenced.

Standard errors are in parentheses.

Source: Derived from KPMG Peat Marwick's Reriremenr Benefits in the 1990s: 1993 and 1994 Survey Data. 


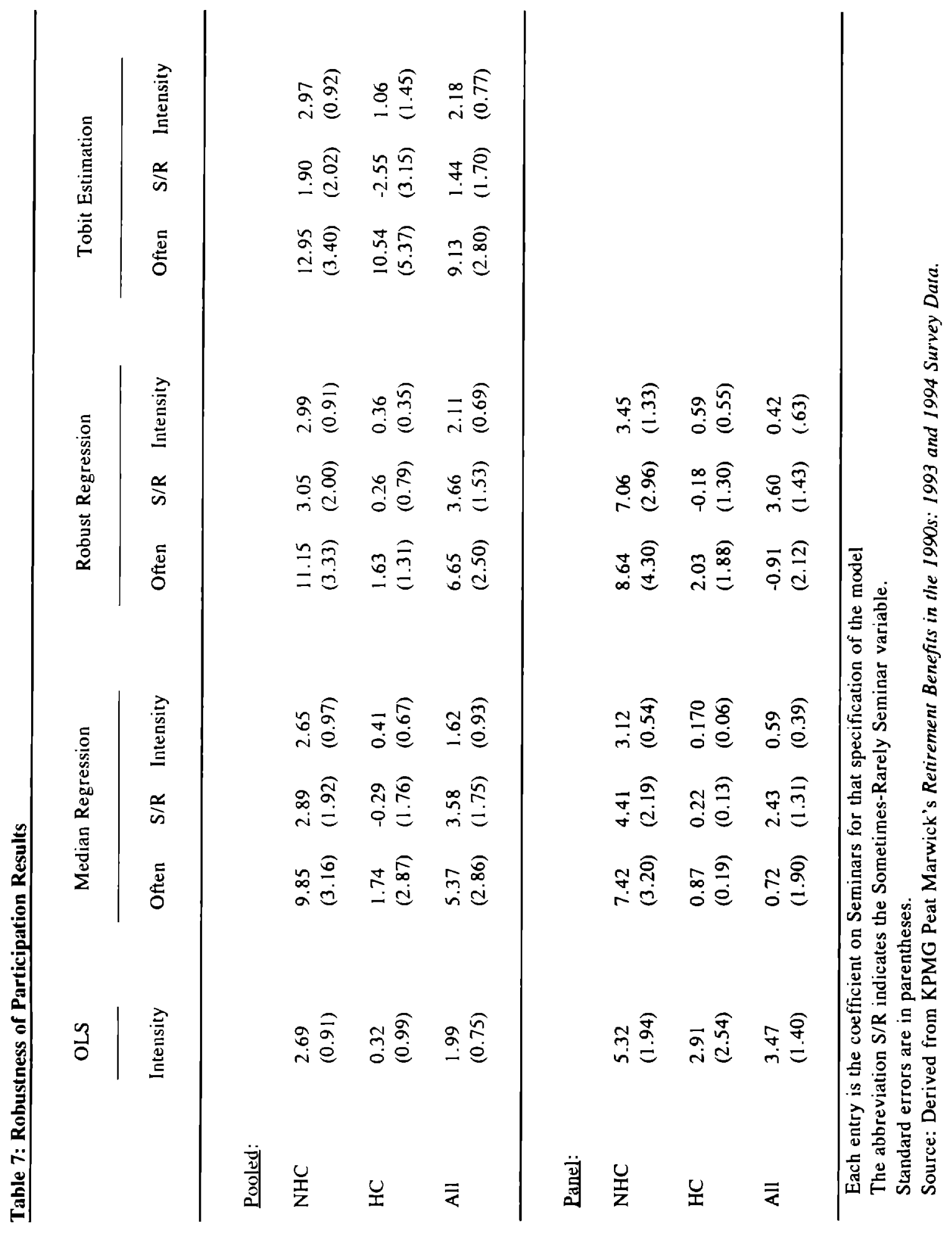


Table 8: Robustness of Contribution Results

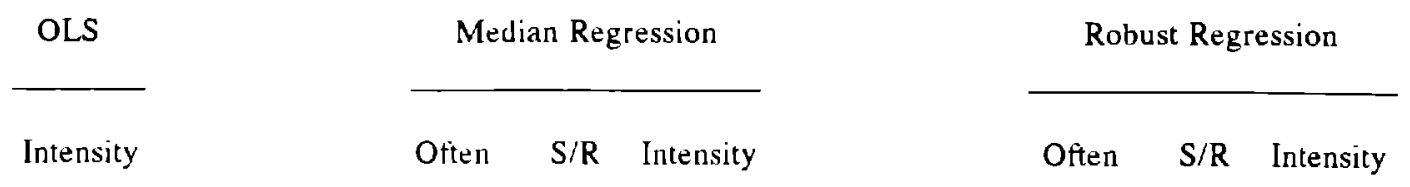

Pooled:

$\begin{array}{lllllllll}\text { NHC } & 0.211 & 0.475 & 0.186 & 0.155 & 0.690 & 0.192 & 0.169 \\ & (.080) & (.363) & (.219) & (.084) & (.254) & (. .153) & (.070) \\ \text { HC } & 0.115 & & & & & & \\ & (.119) & 0.119 & 0.118 & 0.068 & 0.316 & 0.225 & 0.121 \\ & & (.405) & (.247) & (.075) & (.389) & (.231) & (.106) \\ \text { All } & 0.198 & & & & & & & \\ & (.066) & 0.484 & 0.249 & 0.124 & 0.487 & 0.261 & 0.163 \\ & & (.319) & (.192) & (.063) & (.224) & (.135) & (.061)\end{array}$

Panel

$\begin{array}{lllllllll}\text { NHC } & 0.407 & 0.929 & 0.206 & 0.201 & 0.824 & 0.242 & 0.263 \\ & (.153) & (.506) & (.338) & (.084) & (.426) & (.285) & (.123) \\ \text { HC } & 0.219 & & & & & & \\ & (.242) & -0.837 & 0.011 & -0.084 & 0.518 & 0.663 & -0.090 \\ & & (.490) & (.338) & (.110) & (.684) & (.478) & (.202) \\ \text { All } & 0.194 & & & & & & & \\ & (.104) & 0.248 & 0.038 & 0.105 & 0.265 & 0.113 & 0.113 \\ & & (.268) & (.181) & (.105) & (.303) & (.204) & (.091)\end{array}$

Each entry is the coefficient on Seminars for that specitication of the model

The abbreviation $S / R$ indicates the Soinetimes-Rarely Seminar variable.

Standard errors are in parentheses

Source: Derived from KPMG Peat Marwick's Refirement Benefits in the 1990s: 1993 and 1994 Survey Data. 